\title{
Modeling the Whole Firm: The Effect of Multiple Inputs and Financial Intermediation on Bank Deposit Rates
}

\author{
Elizabeth K. Kiser*
}

June 3,2003

\begin{abstract}
Empirical studies of price competition typically analyze the direct effects of market structure, cost, and local demand on prices; this approach has been applied widely to studies of bank deposit rates. However, the theory of the banking firm suggests that substitutability between sources of deposits and conditions in the bank loan market should also affect the pricing of retail deposits. This paper develops a theoretical model to incorporate these effects, and tests the predictions empirically using institution-level deposit rate data from Bank Rate Monitor. The results suggest that the cost of largescale deposits affects how banks price retail deposits, and that conditions in lending markets feed back into retail deposit rates.
\end{abstract}

JEL Codes:

L0-Industrial Organization: General

G2-Financial Institutions and Services

*Economist, Federal Reserve Board, 20th and C St., NW, Washington, DC 20551, elizabeth.k.kiser@frb.gov. The views expressed herein are those of the author and not necessarily those of the Federal Reserve Board. Bob Adams, Dean Amel, Allen Berger, Ron Borzekowski, Ken Brevoort, Diana Hancock, Erik Heitfield, Robin Prager, Alicia Robb, Paul Smith and Christina Wang provided helpful comments. Eli Mou provided research assistance. 


\section{Introduction}

Industrial organization research has paid considerable attention to the effects of market structure, cost, and local demand on pricing. This approach has generally been followed in studies of bank deposit rates. However, for firms with market power, conditions in input and output markets can feed back to affect pricing of both inputs and outputs, and a firm's input mix decision can affect the pricing of the respective inputs. In the case of banking, the theory of the bank as an intermediary - a matchmaker of lenders with borrowers - suggests several such factors that may affect retail deposit rates. First, bank loan and deposit rates may be jointly determined, implying that conditions in loan (output) markets feed back to deposit (input) markets. Second, substitutability among inputs in the production of loans suggests that the prices of different deposit types will affect one another. In particular, a bank's cost of large-scale deposits, for which the bank is a price taker, can affect its pricing of retail deposits, over which it has some market power. These factors have been largely overlooked in the literature on competition for bank deposits. This paper provides a theoretical framework of how intermediation and the input mix decision impact pricing, and tests these predictions empirically.

The model presented here expands on earlier classical models of the banking firm by incorporating factors that affect equilibrium values by shifting retail deposit supply, loan demand and cost, the cost of managing retail deposits, and the cost of attracting and managing wholesale deposits. Comparative static results are tested using a unique data set of directly measured interest rates for four retail deposit products offered by banks and thrifts, linked to data on institution and market characteristics. The directly measured rates are a substantial improvement over commonly used price measures that are computed from balance sheet variables and contain considerable measurement error.

The empirical results show that both bank risk, which affects its cost of wholesale funds, 
and local lending conditions, which influence the pricing of its output, appear to affect retail deposit rates. The findings are consistent with the model's prediction that an institution's lower cost of wholesale funds results in its offering lower retail deposit rates, and that conditions in loan markets can feed back into deposit pricing. These results suggest that the deposit and loan (i.e., the input and output) pricing decisions are not likely separable for most banks. An important implication is that banks are likely to pass through changes in federal funds rates to lending markets - the so-called bank lending channel for monetary policy. The data also indicate that banks with local market power are likely to pay lower deposit rates, confirming the importance of local competitive conditions. Finally, a differential relationship is found between some variables and rates for liquid and time deposits, which implies either that banks do not perceive these products to be perfect substitutes as inputs in the production of loans, or that depositors do not perceive liquid and time deposits to be close substitutes.

\subsection{The Banking Firm}

Banks offer an expanding range of products and services. Nevertheless, banks continue to serve an intermediary function by borrowing funds from depositors and using these to fund lending activities. ${ }^{1}$ As of 2001, total interest income comprised 72 percent of total income for commercial banks in the U.S. ${ }^{2}$, and depository institutions remain the most important source of financing for consumers and small businesses. The process of financial intermediation has received considerable attention in the literature. Traditional theoretical

\footnotetext{
${ }^{1}$ The question has arisen whether deposits should be categorized as inputs or outputs. Hancock (1985) uses the net costs of financial firms' assets and liabilities to determine inputs and outputs. She notes that fluctuations in interest rates and other variables can result in deposits being categorized as either inputs or outputs. In contrast, Sealey and Lindley use the terminology of Frisch (1965), calling deposits a "limitational input" - one whose increase in usage "is a necessary, but not sufficient, condition for an increase in output." (See also Berger and Humphrey (1992).) The analysis here relies on this theoretical notion and designates deposits as inputs.

${ }^{2}$ Source: Federal Deposit Insurance Corporation (FDIC).
} 
models of the banking firm include Tobin (1958), Klein (1971), Monti (1972), and Sealey and Lindley (1977); surveys of this literature are provided in Santomero (1984) and Freixas and Rochet (1997). In these models, the bank is assumed to face an upward-sloping supply of core (retail) deposits and operate as a price taker in a larger-scale funds market (such as federal funds). The bank finances initial loans using less costly core deposits, bidding up the core deposit rate to the point where the marginal cost of core deposits equals the federal funds rate. At this point the bank switches over to federal funds to finance loans at the margin. This model implies that for sufficiently high loan demand relative to core deposit supply, a bank's marginal loan quantity and price may be chosen separately from the quantity and price of core deposits.

Following up on these earlier models, several papers consider the role of funding sources in the "bank lending channel" of monetary policy; see Kashyap and Stein (2000) for a brief review of this literature. The bank lending channel refers to the mechanism by which banks pass through changes in the federal funds rate to the rates they charge on loans. The existence of a bank lending channel relies on the premise that banks have no (major) source of funding other than core deposits and federal funds. If banks use federal funds to fund marginal loans, then the federal funds rate will affect the loan rates banks charge. However, if banks have access to outside funding sources that are less costly than federal funds, banks may be able to make lending decisions that are unaffected by the federal funds rate, and that are separable from retail deposit-taking. Thus, if independence holds between the pricing of core deposits and loans, it follows that the federal funds rate is irrelevant to bank lending decisions, and no bank lending channel for monetary policy exists. In a recent paper, Jayaratne and Morgan (2000) find evidence that limited access to uninsured funds constrains small bank origination of loans, providing evidence in support of a bank lending channel for these institutions, with greater independence between lending and deposit taking (and less of a bank lending channel) for large institutions. 
An extensive body of literature exists on competition in retail deposits, largely distinct from the work on financial intermediation. Much of the work in this area has focused on the relationship between concentration and profits or prices (for example, Berger and Hannan (1989)). Other papers address questions of market definition (Amel and Hannan (1999), Amel and Starr-McCluer (2002) and Heitfield (1999)) and the price effects of mergers (Prager and Hannan 1998); two other papers take a structural approach to evaluating market power (Adams, Röller and Sickles (2002) and Dick (2002)). With the exception of Adams et al. all these papers generally assume independence between deposit taking and lending and do not treat retail deposits as an input in the production of loans. Adams et al. consider the joint decision between deposit and loan rate setting, but perform their analysis at a highly aggregated level. The analysis presented here uses firm-level data to investigate issues raised in both the lending-channel papers and the competition work, and suggests that future work on competition for retail deposits should incorporate alternative sources of funding as well as the effect of lending on retail deposit rates.

\subsection{Retail and Wholesale Deposits}

This study considers the effect of bank access to large-scale, or "wholesale," deposits on retail deposit rates. Banks may differ in their rates paid to obtain wholesale deposits or in their cost of managing wholesale funds. In particular, well capitalized banks with less risky asset portfolios (or banks that are considered "too big to fail") may pay a lower risk premium for wholesale funds than their riskier counterparts. Similarly, larger banks may experience scale economies in managing wholesale deposits and may receive quantity discounts (i.e., lower rates on larger loan volumes), making wholesale funds less costly. If wholesale funds are used as substitutes for retail deposits in funding loans, and if the bank faces an upward-sloping

supply of retail deposits, then its ability to buy wholesale funds at low cost should reduce 
its demand for retail deposits, as it can buy cheap wholesale funds and avoid bidding up the price of the alternative input. This effect, distinct from competitive conditions in local deposit markets, could be increasingly important in explaining how prices are set for retail deposits, as consolidation has resulted in larger, more diversified banks.

The "retail" and "wholesale" categories in the model below are based on the nature of deposit supply. ${ }^{3}$ First, retail and wholesale funds constitute distinct product markets based on depositor substitution patterns and depositor risk. Retail products such as checking and savings accounts and small-denomination certificates of deposit (CDs) are insured by the FDIC and are typically held by individuals or small firms. In contrast, instruments such as large-denomination CDs (those in denominations greater than $\$ 100,000$ ) and subordinated debt are uninsured and tend to be held by larger-scale institutional investors and wealthy individuals. The suppliers of each type of deposit therefore appear to represent distinct sets of customers as well as different degrees of depositor risk. ${ }^{4}$

Second, banks face differing elasticities of supply in retail versus wholesale deposits. Conditional on risk, wholesale funds are homogeneous and exchangeable over a broad (national or international) geographic area, and no single firm holds a substantial market share. In contrast, a depository institution may command some degree of market power (ability to affect prices unilaterally) in retail deposits, arising from several factors. Retail customers' documented use of local depository institutions suggests that firms with large local market shares may hold market power in a local area. ${ }^{5}$ Furthermore, if customer switching costs are present, then even a small institution may hold some market power over its own retail

\footnotetext{
${ }^{3}$ Note that the terms "retail" and "wholesale" in this context do not refer to a vertical sales structure, but rather to two separate deposit markets.

${ }^{4} \mathrm{~A}$ formal test whether retail and wholesale deposits constitute separate product markets would include estimation of cross-elasticities of supply; no data are currently available to perform such estimation.

${ }^{5}$ Amel and Starr-McCluer (2002) use data from the 1998 Survey of Consumer Finances to document the distance between households and their depository institutions. They report that the median distance from a household to its main depository institution has been fairly stable over a 10-year period at 3 miles.
} 
deposit customers. ${ }^{6}$ Finally, differentiation in non-price factors across banking institutions, such as the size and location of ATM or branch networks, may allow some institutions to hold greater market power than if deposit relationships were homogeneous. ${ }^{7}$

Note that although the federal funds rate, referenced in the earlier models, is absent from the model presented below, the reader can consider federal funds to constitute a single component of the broader category of wholesale funds. Note that while the Federal Open Market Committee sets a target for the federal funds rate, the rates paid on individual federal funds transactions between banks vary substantially and depend generally on institution risk. ${ }^{8}$ Hence, rather than considering federal funds to constitute a fixed-rate market at which all institutions can borrow, it should be considered one of several types of large-scale funds which may be substituted for retail deposits.

Interactions between markets for retail and wholesale deposits may be increasing in importance over time as consolidation occurs. Figure 1 shows the ratio of total insured deposits to total liabilities over the period 1992-2001 for banks and thrifts. Over this period the ratio of insured deposits to liabilities dropped from 56 to 40 percent for banks and from 78 to 50 percent for thrifts. This decline was a result of two simultaneous trends: a decline in the ratio of insured to uninsured deposits along with a decline in total deposits as a proportion of total liabilities. ${ }^{9}$ Note that these trends occurred simultaneously with industry consolidation; figure 2 shows that the number of banks fell from 11,462 to 8080 over the period, while the number of thrifts fell from 2390 to 1533. As banks and thrifts have consolidated, they

\footnotetext{
${ }^{6}$ For a survey of the theoretical implications of switching costs, see Klemperer (1995). Kiser (2002) gives empirical results from a survey on household switching behavior at depository institutions. About a third of customers report that a main reason they have maintained their relationship with their depository institution is that it would be too inconvenient to change banks.

${ }^{7}$ Eaton and Lipsey (1996) provide a broad survey of the economics of product differentiation. For a more specialized model of the effect of ATM networks on the pricing of deposit services, see Massoud and Bernhardt (2002).

${ }^{8}$ Furfine (2001) provides an excellent summary of the economics of individual federal funds transactions.

${ }^{9}$ Among nondeposit liabilities, "other borrowed funds" experienced the strongest increase in portfolio share.
} 
appear to rely less heavily on core deposits and draw more funds from larger markets.

\section{The Theoretical Model}

\section{$2.1 \quad$ Setup}

The model developed here is constructed to illustrate the effect of both the input mix decision and intermediation on retail rates. The model is based loosely on the classical models of Klein and Monti, and expanded to incorporate flexible functional forms for deposit supply and loan demand and to introduce shift parameters that affect cost and demand. New comparative statics and welfare effects are then derived to evaluate the impact of changes in model parameters and to make predictions for empirical work.

The model is based on three key assumptions: (1) at low levels of total deposits, banks find retail deposits less costly to obtain and manage than wholesale deposits, (2) banks hold market power in retail deposits and lending but no market power in wholesale deposits, and (3) the retail deposit supply, wholesale deposit supply, and loan demand functions faced by a bank are entirely distinct.

The bank is assumed to take deposits and extend loans. Retail and wholesale deposits are available to the bank as perfectly substitutable inputs in the production of loans. Fee income and revenue from investment activities other than lending are excluded, and no reserve requirement appears in the model. The primary results are not dependent on these assumptions. The exposition describes a monopoly bank; however, this type of model can be extended to a case of imperfect competition which gives similar comparative static results. ${ }^{10}$

The bank produces loans according to a linear production function, where the quantity of loans $L$ produced is less than or equal to the sum of retail deposits $D_{R}$ and wholesale

\footnotetext{
${ }^{10}$ See Freixas and Rochet (1997) p. 60.
} 
deposits $D_{W}$ taken:

$$
L\left(D_{R}, D_{W}\right) \leq D_{R}+D_{W}
$$

The bank faces an inverse demand for loans $r_{L}(L)$, an inverse supply of retail deposits $r_{R}\left(D_{R}\right)$, and a perfectly elastic supply of wholesale deposits $D_{W}$ at rate $\bar{r}_{W}$. Assume a standard, upward-sloping retail deposit supply function that satisfies the following conditions:

$$
\begin{aligned}
& r_{R}^{\prime}>0 \quad \forall D_{R}>0, \\
& r_{R}^{\prime}(0)<\infty \\
& 2 r_{R}^{\prime}+D_{R} r_{R}^{\prime \prime} \geq 0 \quad \forall D_{R}>0 .
\end{aligned}
$$

Assume a standard downward-sloping loan demand function, with:

$$
\begin{array}{r}
r_{L}^{\prime}<0 \quad \forall L>0, \\
r_{L}^{\prime}(0)>-\infty, \\
2 r_{L}^{\prime}+L r_{L}^{\prime \prime} \leq 0 \quad \forall L>0 .
\end{array}
$$

These functional forms are more general than the linear case presented in the Klein and Monti models. Weak convexity of retail deposit supply is sufficient but not necessary to satisfy the final condition in (2); this assumption is standard in Cournot models and is not restrictive. Similarly, the final expression in (3) is a less restrictive condition than weak concavity.

Let $r_{R}(0)$ designate the retail rate that induces the first unit of retail deposits to be supplied. Assume that this value is less than the wholesale rate:

$$
r_{R}(0)<\bar{r}_{W}
$$


The monotonicity of retail deposit supply along with (4) implies that for the first unit of loans, the marginal cost to the bank of retail deposits is less than the marginal cost of wholesale funds. The assumptions in (4) and (2) imply that the bank's marginal cost curves for retail and wholesale deposits intersect.

Define $\tilde{D}_{R}$ as the level of retail deposits such that the marginal cost of retail deposits equals the marginal cost of wholesale deposits; that is, $\tilde{D}_{R}$ satisfies

$$
r_{R}\left(\tilde{D}_{R}\right)+\tilde{D}_{R} r_{R}^{\prime}\left(\tilde{D}_{R}\right)=\bar{r}_{W}
$$

The assumptions in (2) and (4) imply that $\tilde{D}_{R}$ is nonnegative. The bank's cost-minimization problem results in the following cost function:

$$
C\left(r_{R}, \bar{r}_{W}, L\right)= \begin{cases}r_{R}(L) L & \text { if } L \leq \tilde{D}_{R} \\ r_{R}\left(\tilde{D}_{R}\right) \tilde{D}_{R}+\bar{r}_{W}\left[L-\tilde{D}_{R}\right] & \text { otherwise }\end{cases}
$$

\subsection{Profit Maximization}

The bank's profit equals loan revenue minus deposit interest. The firm's profit-maximization problem is

$$
\max _{L} \Pi(L)= \begin{cases}{\left[r_{L}(L)-r_{R}(L)\right] L} & \text { if } L \leq \tilde{D}_{R} \\ r_{L}(L) L-r_{R}\left(\tilde{D}_{R}\right) \tilde{D}_{R}-\bar{r}_{W}\left[L-\tilde{D}_{R}\right] & \text { otherwise }\end{cases}
$$

Because the bank's marginal cost of deposits is continuous and weakly increasing and its marginal loan revenue is continuous and strictly decreasing, a unique maximum exists. Define

$$
L^{*}=\arg \max _{L} \Pi(L)
$$

For total lending levels below $\tilde{D}_{R}$, profit maximization reduces to simple monopoly quantity 
setting with downward-sloping demand and increasing marginal cost. Beyond this point, the bank funds marginal loans with wholesale deposits, while retaining the retail deposits obtained up to the switch point $\tilde{D}_{R}$. Thus, $L^{*}$ satisfies the first-order condition

$$
r_{L}(L)+L r_{L}^{\prime}(L)=\min \left\{r_{R}(L)+L r_{R}^{\prime}(L), \bar{r}_{W}\right\}
$$

The resulting demand for retail deposits is

$$
D_{R}^{*}= \begin{cases}L^{*} & \text { if } L^{*} \leq \tilde{D}_{R} \\ \tilde{D}_{R} & \text { otherwise }\end{cases}
$$

and the demand for wholesale deposits is

$$
D_{W}^{*}= \begin{cases}0 & \text { if } L^{*} \leq \tilde{D}_{R} \\ L^{*}-\tilde{D}_{R} & \text { otherwise }\end{cases}
$$

These relationships are illustrated in figure 3. In the left graph, the bank has no source of funding beyond retail deposits. Accordingly, it sets marginal loan revenue equal to marginal deposit cost, and extends $L^{0}$ loans equal to the amount of retail deposits $D_{R}^{0}$. The equilibrium retail deposit and loan rates are $r_{R}^{0}$ and $r_{L}^{0}$. In the right graph, wholesale funds are available to the bank at rate $\bar{r}_{W}$, implying that the heavy dashed line forms the bank's marginal deposit cost curve, with a kink occurring at $\tilde{D}_{R}$. In equilibrium, the bank increases its total lending to $L^{1}$, holds retail deposits $D_{R}^{1}$ equal to $\tilde{D}_{R}$, and holds wholesale deposits in the amount of $D_{W}^{1}$. The loan rate drops to $r_{L}^{1}$, and the retail deposit rate drops to $r_{R}^{1}$.

\subsection{Theoretical Predictions}

As is derived in appendix A, an increase in the wholesale funds rate $\bar{r}_{W}$ increases the equilibrium retail deposit rate. The level of $\bar{r}_{W}$ the bank faces should be interpreted to result 
from a bank's portfolio risk. While the theoretical model takes $\bar{r}_{W}$ to be exogenous, the empirical model presumes that heterogeneity in risk across banks results in differing rates paid for large-denomination funds.

In addition to the wholesale rate, other factors that shift demand, cost and risk may also affect retail rates. These factors, which were absent in the Klein-Monti models, can be incorporated in a straightforward way. Comparative static results for retail deposit operating $\operatorname{cost} \theta_{R}$, wholesale deposit operating $\operatorname{cost} \theta_{W}$, loan operating $\operatorname{cost} \theta_{L}$, retail deposit supply $\sigma_{R}$, and loan demand $\sigma_{L}$ are derived in appendix $\mathrm{A}$ and summarized in table 1. Most predicted signs depend on the range of output, according to whether $L^{*}$ exceeds $\tilde{D}_{R}$ (whether wholesale funds are employed).

Most of the expected signs are straightforward; a few are initially counterintuitive. Note that for a level of retail deposits below the switch point $\tilde{D}_{R}$, an increase in retail deposit operating cost increases the total marginal cost of deposit taking by the bank, thereby decreasing the optimal level of lending and deposit taking. Because retail deposit supply slopes upward, this results in a decrease in the equilibrium retail deposit rate. Similarly, an increase in loan operating cost results in a decrease in the optimal level of lending and deposit taking, and in turn a decrease in the retail deposit rate paid.

The model is constructed to illustrate the effects of the input mix decision and intermediation on retail rates. The model could be extended easily to allow for an increasing marginal cost of wholesale funds (or multiple types of substitutable funds). In this case, the bank would equilibrate the marginal cost of each deposit type to marginal loan revenue. Assuming that the marginal cost of each deposit type is increasing, and if the rates required to attract the first dollar of each deposit type are similar, it would be profitable to use a single deposit type only at low levels of lending. Once rates are bid up to attract the initial dollar of each deposit type, it would never be profitable to use only one deposit type at the margin. Substitution among deposit types would be continuous rather than discrete, 
and no switchover point analogous to $\tilde{D}_{R}$ would exist. Consequently, the (nonzero) signs of the derivatives shown in table 1 would apply regardless of whether the bank is employing wholesale funds.

\subsection{Welfare Effects}

The comparative statics show that a lower cost of wholesale funds results in greater total lending and lower loan rates. It follows that a lower $\bar{r}_{W}$ should increase borrower welfare. However, decreasing $\bar{r}_{W}$ also decreases both retail deposits and the rate paid to retail depositors. The effect of the cost of wholesale funds on borrower, depositor and bank surplus and the net effect on total welfare is calculated in appendix B. Note that because the wholesale rate $\bar{r}_{W}$ is assumed to be determined in a perfectly competitive market, zero economic profits accrue to wholesale depositors. Also, because the wholesale funds rate has no effect when the bank does not find it profitable to use wholesale funds, only the case where $D_{W}^{*}>0$ is considered.

The derivation shows that the effect on total surplus of the wholesale funds rate depends on the relative curvature and magnitudes of retail deposit supply and loan demand. Symmetric curvature of retail deposit supply and loan demand results in the gains to borrowers from a drop in $\bar{r}_{W}$ exceeding the corresponding loss to retail depositors. (This result is driven by the assumption that wholesale depositors receive zero surplus.) This observation is important from a policy perspective; while we might infer that less competitive retail deposit rates are a negative outcome of an increase in institution size, this loss in consumer surplus may be more than offset by lower loan rates, all else equal. This assumes, of course, that the competitive environment is held constant. Aside from the model, increasing firm size through consolidation could also result in greater market power in both loans and deposits, so that the increase in consumer surplus from cheaper wholesale funds could in turn be offset 
by increased rates due to greater market power.

\section{Empirical Estimation}

The empirical model differs from the theoretical model in a few ways. Most notably, the markets for retail deposits and loans are assumed in the theoretical model to be monopoly markets; no strategic interaction occurs among firms. Recall that the model can be extended to incorporate imperfect competition among several firms.

While the theoretical model examines the decision of a single bank facing a single wholesale funds rate, banks in the population vary in the rates they must pay for wholesale funds (as well as along other dimensions). The empirical analysis is conducted under the assumption that each bank is a price taker in wholesale deposits, and that levels of $\bar{r}_{W}$ vary across the population of banks. The process generating these differences in wholesale rates is not modeled here; however, the empirical models are based on the premise that wholesale rate or cost differences may result from differences in bank risk, scale, or differences in cost or demand.

Equation (9) can be solved implicitly for $r_{R}^{*}$ as

$$
r_{R}^{*}=f\left(\bar{r}_{W}, \theta_{W}, \theta_{R}, \sigma_{R}, \sigma_{L}, \theta_{L}\right)
$$

Two model specifications are estimated, both as linearized versions of this reduced form. The first model specification is run in an OLS framework:

$$
r_{i m}^{p}=\beta^{p '} X_{i m}+\epsilon_{i m}^{p}
$$

where $p \in\{1, \ldots, 4\}$ indexes four specific retail deposit products (interest checking accounts, MMDAs, and 6- and 12-month CDs), $i$ indexes institutions, and $m$ indexes markets. $X_{i m}$ is 
a vector of proxies for the arguments in equation (12) as well as other control variables, and $\beta^{p}$ is a vector of parameters to be estimated for each product. All unobservable components of the arguments in (12) are subsumed in the error $\epsilon_{i m}^{p}$ which is assumed to be iid across institutions and markets.

One concern with the OLS specification arises because the same institutions may appear in multiple markets, implying a violation of the iid assumption on $\epsilon_{i m}^{p}$. To account for the correlation among observations on the same institution, a random-effects model is estimated as the second specification:

$$
r_{i m}^{p}=\beta^{p \prime} X_{i m}+u_{i}^{p}+\epsilon_{i m}^{p}
$$

The unobserved institution-specific random effect $u_{i}^{p}$ is assumed to be constant across all observations on a given institution and distributed standard normal. The model is estimated using maximum likelihood, with the institution/market-specific disturbance $\epsilon_{i m}^{p}$ assumed to be iid standard normal. Note that in both the OLS and random-effects specifications, each equation is estimated separately and not in a stacked regression framework. ${ }^{11}$

\subsection{Data}

Deposit interest rates paid on the four types of retail deposit rates were provided by Bank Rate Monitor. The data set is a cross section of 437 distinct banks and thrifts operating in 113 metropolitan areas in the first week of June 1998 (thrifts constitute just under a third of the observations in the sample). The level of observation is the institution in a local market. ${ }^{12}$ Several institutions appear in multiple markets in the sample, as the total sample size of bank/market pairs is $806 .{ }^{13}$ The survey included up to five banks and five thrifts with the

\footnotetext{
${ }^{11}$ Because no cross-equation restrictions are to be tested, the model is not estimated in a seemingly unrelated regressions (SUR) framework.

${ }^{12}$ Appendix $\mathrm{C}$ lists the BRM markets. The BRM data are available for these MSA markets only; no rural areas are included.

${ }^{13}$ Note that not all the observations are used in estimation due to missing regressors.
} 
largest deposit market shares in each market; the median assets across institution/market observations in the sample is $\$ 7.8$ billion. ${ }^{14}$ While the sample slightly overrepresents thrift institutions, it does generally represent the largest-share institutions operating in the largest metropolitan areas. Because of the emphasis on larger institutions, this sample is arguably more appropriate than a representative sample of U.S. depository institutions for examining the effects of wholesale funds markets on retail prices, as one would expect larger institutions to be more likely than smaller institutions to participate heavily in markets for wholesale funds.

In addition to the stratification scheme, the Bank Rate Monitor data are particularly useful for this application because they are directly measured and available for multiple products. Directly measured retail deposit rates are often difficult to obtain. The rates used in many studies are computed from institution income statements and balance sheets and are available only at the institution and not the market level, which presents a problem in the case of multi-market institutions. In addition, comparable numbers for specific deposit products are generally not available for both banks and thrifts. Aggregating over markets and deposit products to construct prices can result in considerable measurement error. In addition, the availability in this sample of several types of deposit rates means that separate estimates can be obtained for products for which consumer demand, firm cost, or competition may vary. Furthermore, the results from estimation using multiple products can be compared to determine whether patterns are spurious or systematic.

Many variables from other sources are linked to the Bank Rate Monitor data. How these variables serve as proxies for components of the profit function is described below. Means and standard deviations of variables are presented in table 2.

\footnotetext{
${ }^{14}$ Some markets contained fewer than five institutions of each type, so some markets total fewer than ten institutions.
} 


\subsubsection{Wholesale Funds Interest Cost}

Because no data are available on the actual rates paid by banks on wholesale funds, two approaches are used here to measure the cost of such funds - one direct measure of a wholesale interest rate calculated from institution balance sheets, and several firm-level proxies of institution risk. ${ }^{15}$

The direct rate measure is the interest rate for interest paid on subordinated debt, computed at the institution level. This variable is equal to the institution's subordinated debt interest expense divided by total subordinated debt outstanding. This rate is interacted with an indicator for whether the institution has subordinated debt outstanding.

One proxy for institution risk is an indicator of whether Moody's rates the institution's senior debt. ${ }^{16}$ No finer gradation of actual ratings was included, as little variation in ratings was present for these institutions. Two balance-sheet measures are included as risk proxies: the ratio of capital to the book value of assets, which may reflect liquidity risk, and the ratio of nonaccrual loans to assets, which may be correlated with portfolio risk.

A measure of institution size is also included: the log of total bank holding company (BHC) assets if the institution is part of a BHC, and the log of total institution assets otherwise. ${ }^{17}$ Large banking organizations are more likely than smaller institutions to hold diversified asset portfolios, both geographically and by asset type and maturity, implying a lower probability of defaulting on obligations such as uninsured deposits, all else equal, and (potentially) lower large-scale deposit rates. Large firms also typically have greater brand recognition or perceptions of being "too big to fail," which could imply lower perceived risk to some investors. Finally, an indicator of whether the institution operates in multiple states

\footnotetext{
${ }^{15}$ Balance sheet variables are taken from the 1998 Reports of Condition and Income from the Federal Financial Institutions Examination Council for banks, and the Thrift Financial Reports from the Office of Thrift Supervision for thrifts.

${ }^{16}$ Thanks are due to Daniel Covitz for assistance in obtaining this variable.

${ }^{17}$ The log form is included because of the extreme skewness of the asset distribution; one would not expect the marginal effect of assets to be the same for moderate-size and very large institutions.
} 
is included to reflect geographic diversification.

\subsubsection{Wholesale Funds Operating Cost}

A bank's cost of managing wholesale funds is likely affected by the scale of operation, which should be reflected in the log assets variable. Large institutions may also receive quantity discounts from large-scale depositors. Because costs specific to institution headquarters locations may also affect operational costs for wholesale fund management, the regressions include the median wage of financial managers in the city where the institution is headquartered. ${ }^{18}$ Note that this wage variable is market- rather than bank-specific.

\subsubsection{Retail Deposit Supply}

Many market-level demographic variables may affect the supply of retail deposits. Percapita income, population density, and population are included in the model. Institution characteristics may also affect customers' willingness to supply funds, through unobserved institution quality (e.g., customer service) or heterogeneous customer tastes for specific services. Some customers, for example, may be willing to supply funds at lower rates in order to receive access to extensive ATM or branch networks. The model includes the institution's local branch market share, as well as the total number of markets in which the institution operates, which should capture customer preference for a large network. ${ }^{19}$ Also, the thrift indicator may reflect customer preference for unobserved characteristics associated with a particular type of institution.

\footnotetext{
${ }^{18}$ Financial manager wages for 1998 come from the Bureau of Labor Statistics' Occupational Employment Survey.

${ }^{19}$ For institutions that are held by a bank holding company (BHC), the number of markets is that of the BHC.
} 


\subsubsection{Retail Deposit Operating Cost}

Local market conditions may affect the cost of receiving and managing retail deposits; the median local teller wage is included to account for some such differences. ${ }^{20}$ Measures of the expense of bank-level labor and physical capital are included in four variables: the ratio of the expense of premises and fixed assets to the value of such assets, average salary per employee, and employees per branch.

Market population, population density and per-capita income could also reflect retail operating costs. ${ }^{21}$ Finally, the thrift indicator may capture any systematic cost differences (along with other differences) between thrifts and banks.

\subsubsection{Loan Demand, Operating Cost, and Risk}

Some market-level measures, such as per-capita income and population density, may also influence loan demand. Local unemployment rates are included as additional loan demand shifters. State-level mortgage delinquency rates are included to reflect the greater risk of extending loans in the respective state, which should shift lending in the same direction as an increase in the operational cost of lending. The median loan officer wage in the local market is included to reflect labor cost differences. ${ }^{22}$

\subsubsection{Local Competitive Environment}

As has often been included in the existing literature, the Herfindahl-Hirschman Index (HHI) of local market deposits is included to reflect the degree of local concentration, which may

\footnotetext{
${ }^{20}$ Market-level teller wages for 1998 come from the Bureau of Labor Statistics' Occupational Employment Survey.

${ }^{21}$ Population and income measures are created using 1990 Census and 1998 Current Population Survey data.

${ }^{22}$ Market-level loan officer wages for 1998 come from the Bureau of Labor Statistics' Occupational Employment Survey.
} 
affect pricing. ${ }^{23}$ In addition, the model includes the rate of household migration into the market. ${ }^{24}$ This variable reflects the proportion of customers in the market who are induced by relocation to choose a new bank and thereby are not affected by switching costs in their choice of institution. Switching costs often result in higher equilibrium prices by reducing the cross-elasticities of demand across institutions. ${ }^{25}$ Finally, the local branch share could be an indicator of the bank's own local market power.

\section{Results}

The OLS and random-effects regression results are presented in detail in tables 3 and $4 .^{26}$ Ideally one would perform a specification test to determine whether the random effect is correlated with the prediction error, as in Hausman (1978). However, because the data set contains only a single observation per institution for a substantial portion of institutions, it is impossible to construct the relevant test statistic. ${ }^{27}$ The random-effects results are presented alongside the OLS estimates with the caveat that the random-effects estimates are inconsistent if the random effect $u_{i}^{p}$ is in fact correlated with the disturbance $\epsilon_{i m}^{p}$.

The strongest and most robust findings on the risk measures are the coefficients on nonaccrual loans/assets and $\ln$ (assets). Recall the prediction from the theoretical model, with a linear example illustrated in figure 3, that an institution with higher risk (i.e., a higher level of $\bar{r}_{w}$ ) pays a higher retail deposit rate $r_{R}$ in equilibrium. For nonaccrual loans/assets,

\footnotetext{
${ }^{23}$ Information on market-level bank deposits and branches, including measures of market concentration, come from the FDIC's 1998 Summary of Deposits.

${ }^{24}$ This variable measures the proportion of local 1997 tax filers new to the market since 1996. These data were provided by the Internal Revenue Service's Statistics of Income Division. Because the number of tax returns approximates the number of household economic units, this measure of migration is likely a better proxy for new banking customers than population migration.

${ }^{25}$ Sharpe (1997) finds deposit rates to be higher in markets with greater population turnover.

${ }^{26}$ Some regression variables are scaled differently from those in the descriptive statistics in table 2 .

${ }^{27}$ The Hausman test relies on a comparison between the coefficient estimates from the random-effects and fixed-effects models. Because of the absence of repeat observations for all institutions, the fixed effects themselves cannot be estimated, implying that the Hausman test statistic cannot be obtained from this sample.
} 
a measure of portfolio risk, the coefficients are positive and statistically significant for all deposit products in the OLS regression and for two of the four products in the random-effects specifications. The exact interpretation of this coefficient depends on whether one views nonaccrual loans/assets as an ex ante or ex post measure of risk. If the ratio is considered an ex ante risk measure, then the positive coefficient is consistent with the view that inherently riskier banks must pay higher wholesale rates and consequently find it profitable to bid up the price of retail deposits, the substitute input. If nonaccrual loans/assets are considered an ex post risk measure, the coefficient is consistent with the phenomenon of distressed banks facing liquidity problems driving up retail deposit rates in order to continue operations.

The coefficient on total assets is negative and significant for all products in both regression specifications. This outcome is consistent with the explanation that large institutions have access to lower-cost wholesale funds, through either lower real or perceived risk or through scale economies in attracting or managing these funds. The finding on institution size could also be considered consistent with a customer preference for a large network; however, the regressions control for the number of markets in which the institution operates as well as the local branch share. The remaining importance of institution size could also possibly represent a consumer preference for services unobserved in the data that are provided only by large institutions. Regardless, the coefficients are consistent with the wholesale funds explanation. Note also that while the negative coefficient on assets is consistent with scale economies in wholesale deposit taking, it is clearly inconsistent with scale economies in retail deposit taking.

The role of individual loan market risk in deposit price setting, proxied by the state mortgage delinquency rate, appears to be strongly related to retail deposit rates. In figure 3, an increase in an institution's cost or risk of lending has the same directional effect on equilibrium retail deposit rates as an inward shift in loan demand $r_{L}(L)$ and loan marginal revenue $r_{L}^{\prime}$. A higher state mortgage delinquency rate is therefore predicted to result in an 
associated lower retail deposit interest rate. This variable indeed shows negative coefficients in all regressions, with statistical significance in seven of the eight. Because other economic factors in the local market (unemployment, income, population and population density) were controlled for, it appears unlikely that this coefficient estimate comes from a spurious correlation based on unobserved economic factors that could affect retail deposit supply. These results suggest an absence of separability between deposit-taking and lending. To check the robustness of this finding, the regressions were performed separately for institutions with assets over $\$ 50$ million, and separately for thrifts and banks. The mortgage delinquency coefficient was still negative and statistically significant even in the regressions for banks only and for large institutions only (the results are not reported here). Thus, there appears to be no difference in this result for larger institutions that are more likely to have access to wholesale funds as opposed to smaller, less diversified institutions. This conclusion contrasts somewhat with that of Jayaratne and Morgan (2000), who find that lending is separable from retail deposits for large institutions only.

The market-level measure of retail deposit operating cost, teller wages, appears important for rate setting. A higher retail deposit operating cost would shift the retail deposit marginal cost curve up and left without affecting retail deposit supply (see section A.2); the model predicts lower retail deposit rates from higher retail operating costs. The coefficient on local teller wages is indeed negative in all the regressions and highly statistically significant in seven of the eight. This effect is consistent with higher variable costs of managing retail deposits resulting in lower rates. One of the institution-level retail cost measures, the ratio of the fixed assets expense to fixed assets, is negative and statistically significant in the OLS regression for interest checking, consistent with the result on teller wages. In contrast, the coefficients on salaries per employee are positive in all but the interest checking regressions. This finding could stem from unobserved differences in institution service levels. The coefficient on employees per branch is positive and significant only in the case of OLS interest 
checking.

Consistent with the competition literature, both the branch share and market concentration are related to retail rates. The institution's branch share in the local market could represent either local market power or customer preference for a large branch network; both effects predict a negative sign. The coefficient on this variable is in fact negative and highly significant for CDs in both the OLS and random-effects specifications, and for MMDAs in the OLS case (the exception is the OLS interest checking coefficient, which is positive and significant at the 10 percent level). The differential findings for checking versus MMDAs and CDs may result in part from unobserved checking account fees.

The coefficient on local market concentration as measured by the branch HHI is negative and significant in the checking regression in both the OLS and random effects case, and for MMDA in the OLS regression; CDs do not show a statistically significant coefficient in either specification. While previous research has shown a somewhat stronger negative relationship between concentration and deposit rates, it is important to note that the institutions included in the current study are located in large markets, which tend also to be the least concentrated markets. The data set contains relatively little variation in concentration across observations.

Thrift institutions appear to pay higher rates than banks, all else equal. It is unclear from these regressions whether this difference results from differences in cost, demand, or competition. Because the bundle of services offered by thrifts may be more limited than that of banks, thrifts may need to pay better rates than banks on average to attract customers.

The indicator for whether the institution issues subordinated debt and the average rate paid on such debt interacted with the issuance indicator show weak results across products and model specifications. This effect may be due to the compositional effects of firms that do or do not issue subordinated debt, as subordinated debt issuance was not mandatory. Specifically, it is unclear whether riskier or less risky firms would choose to issue subordinated debt, all else equal. 
The variable indicating whether the institution is rated by Moody's is negative, as predicted, and statistically different from zero only in the case of 12-month CDs in the random effects model. Given the lack of heterogeneity in the ratings themselves, it is possible that investors derive little information from the rated indicator.

The capital/assets ratio is curiously positive and significant in both MMDA regressions yet negative and significant in both 12 -month $\mathrm{CD}$ regressions. It is possible that this ratio has different implications for insured deposits of different terms. Also, because riskier firms could increase capital to offset a risky portfolio, the ratio may be a poor indicator of portfolio safety.

The variables measuring geographic diversification, the multistate indicator and the number of markets in which the institution operates, also show a weak relationship to retail rates. Regardless, these variables can be considered controls for network coverage when interpreting other coefficients such as those on $\ln$ (assets) and branch share.

The coefficients on the wage of loan officers in the local market are unexpectedly positive and statistically significant in four of the eight regressions. It is possible that correlation with the model's other wage variables is influencing this result (the loan officer, teller, and financial manager wages are all positively correlated).

The rate of population migration into the market does not have a statistically significant coefficient in any regression. However, this departure from previous findings (e.g. Sharpe) may again reflect the fact that this data set is composed of observations from large markets, which tend to have higher than average population turnover.

The results for the region dummies are similar within deposit types, but differ across types. Interest checking and money-market rates show few differences relative to the omitted region (Pacific), but CD rates show much stronger differences. 


\section{Conclusion}

This paper investigates the role the input mix decision and financial intermediation play in the pricing of retail deposits, an input over which the bank has some market power. The empirical models are estimated using a unique data set of directly measured retail deposit rates for several specific products, linked to other data on firm and market characteristics. The results indicate that both the input mix and conditions in the output market affect the pricing of the input. Specifically, factors related to institution size and portfolio risk, local loan risk, local cost, charter type, and local market power in retail deposits are predictive of retail deposit rates, supporting the predictions of the theoretical model. Large institutions are associated with lower retail rates, even after controlling for the local market share and the number of markets in which the bank operates, and institutions with a greater share of nonperforming loans pay higher retail deposit rates. These findings are consistent with the ability of larger institutions with access to cheaper wholesale funds to pay lower retail deposit rates.

The strong relationship between retail deposit rates and state mortgage delinquency rates supports the view that feedback occurs between conditions in loan and deposit markets, and that loan and deposit rates are set simultaneously. This finding implies that banks should be responsive to the federal funds rate, so that monetary policy actions flow through to affect bank loan rates. The results on local retail deposit operating costs and the bank's market power are consistent with the previous competition literature. Thus, financial intermediation

and the input mix decision appear to strongly affect retail deposit pricing alongside the local retail deposit competitive environment.

The model's conclusions illustrate the point that a complete picture of price setting in any specific product market should reflect the full range of activities in which each firm engages and should incorporate firm heterogeneity in these activities. If market power exists in input 
or output markets, pricing depends on the individual firm's choice set. For the financial services sector, the results from this study suggest that research on competition can be improved applying models using a "whole bank" approach. Further work in this area could include structural models that take all these elements into account; for example, modeling local oligopolistic interaction similarly to Dick (2002) while incorporating deposit-taking, lending and funding decisions as do Adams et al. (2002). Finally, additional research could consider how portfolio allocation decisions on the asset side of the balance sheet (for example, between retail lending and other investment activities) interact with input-mix decisions on the liability side to affect the price formation of all products in the multi-product firm. 
Figure 1: Ratio of total insured deposits to total liabilities, 1992-2001.

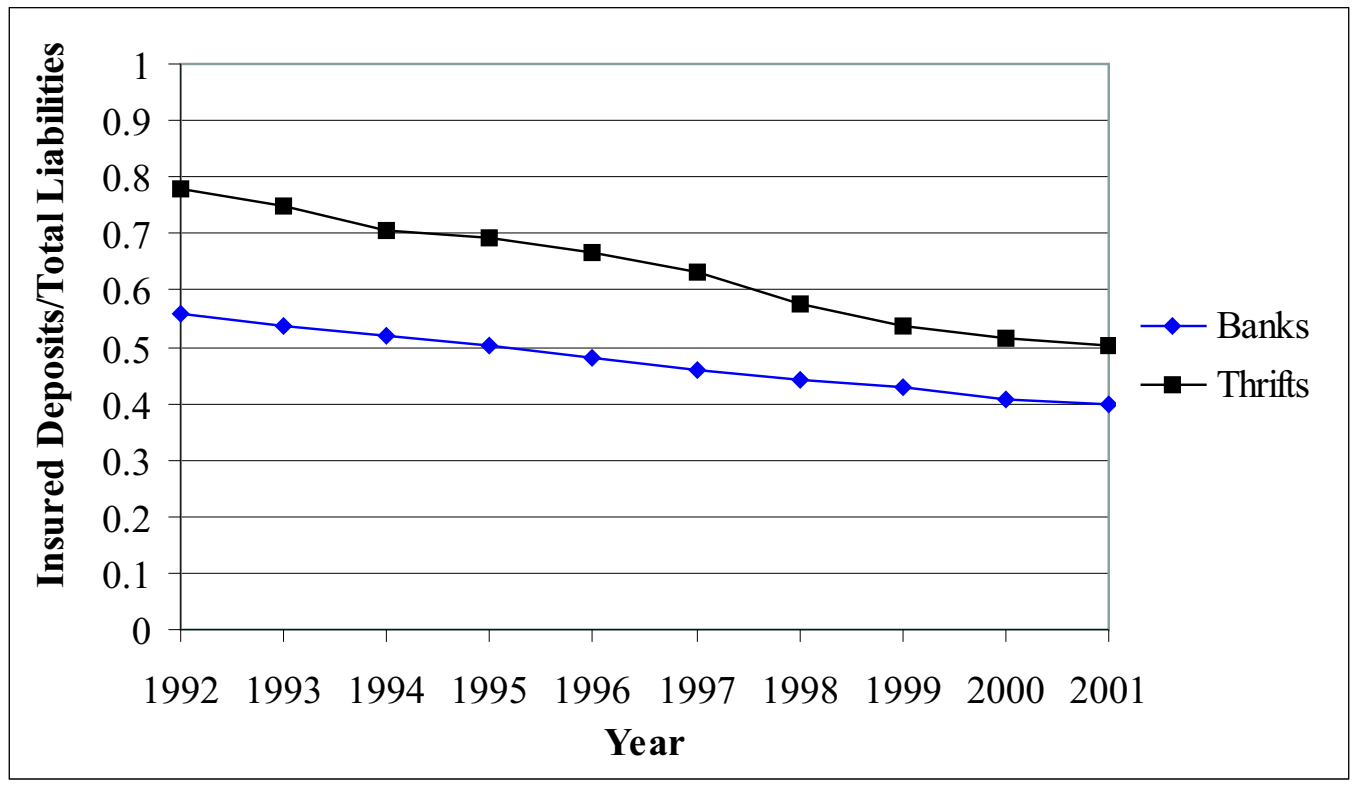


Figure 2: Total number of banks and thrifts, 1992-2001.

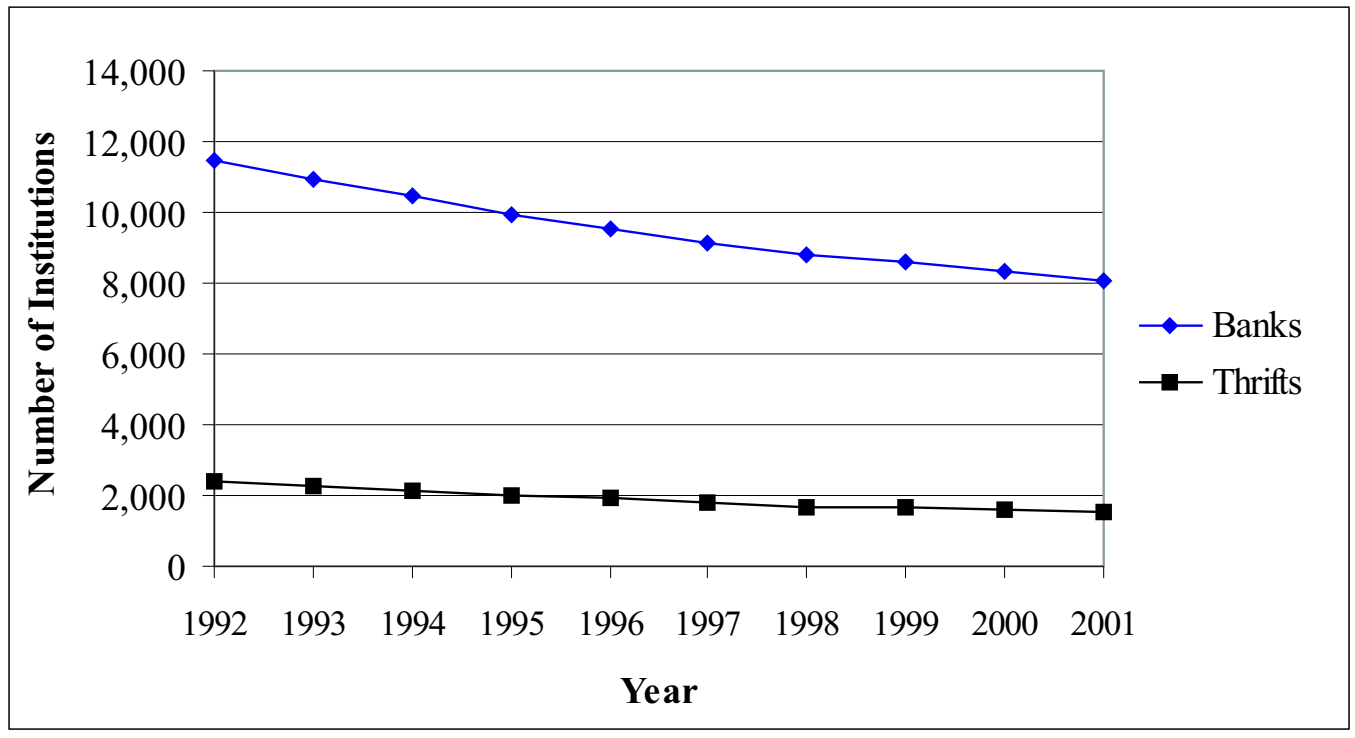


Figure 3: Equilibrium rates and deposits when wholesale funds are unavailable (left) and available (right).
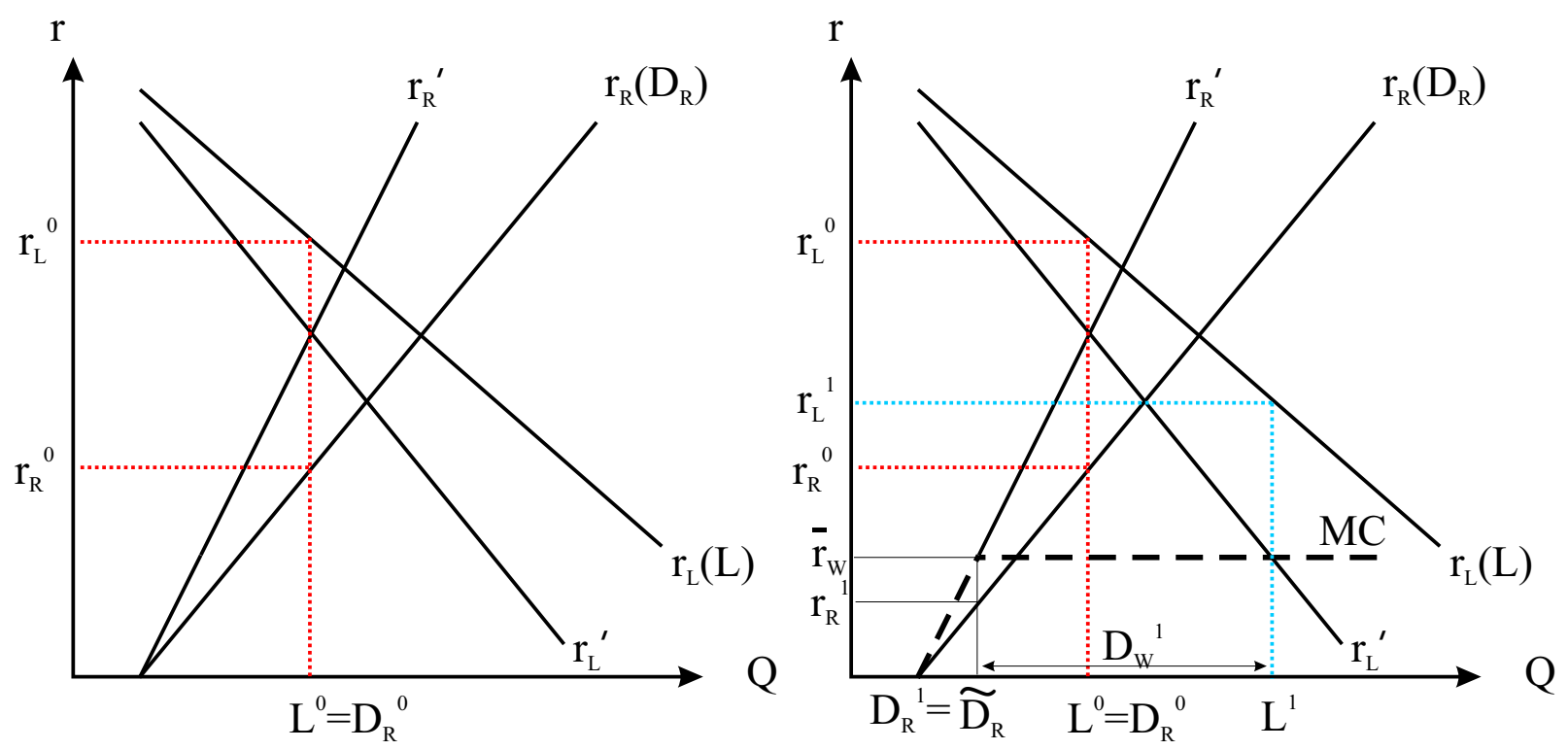
Table 1: Theoretical predictions of effects of changes in model parameters on the retail deposit rate.

\begin{tabular}{l|c|c}
\hline & \multicolumn{2}{|c}{ Predicted effect on $r_{R}^{*}$ if: } \\
Parameter & $L^{*} \leq \tilde{D}_{R}$ & $L^{*}>\tilde{D}_{R}$ \\
\hline \hline wholesale funds rate $\bar{r}_{W}$ & 0 & + \\
\hline wholesale operating cost $\theta_{W}$ & 0 & + \\
\hline retail deposit operating $\operatorname{cost} \theta_{R}$ & - & 0 \\
\hline retail deposit supply $\sigma_{R}$ & - & 0 \\
\hline loan demand $\sigma_{L}$ & + & 0 \\
\hline loan operating $\operatorname{cost} \theta_{L}$ & - & 0 \\
\hline
\end{tabular}


Table 2: Descriptive Statistics

\begin{tabular}{l|c|c|c|c}
\hline Variable & Mean & Median & St Dev & N \\
\hline \hline Interest checking rate & 1.357 & 1.15 & 0.531 & 777 \\
MMDA rate & 2.410 & 2.33 & 0.640 & 770 \\
6-month CD rate & 4.613 & 4.7 & 0.494 & 800 \\
12-month CD rate & 4.876 & 4.91 & 0.436 & 800 \\
Issues subordinated debt & 0.673 & 1 & 0.470 & 800 \\
(Issues sub. debt)*(s.d. rate) & 1.139 & 0 & 0.881 & 788 \\
Rated & 0.411 & 0 & 0.492 & 800 \\
Capital/assets & 0.086 & 0.080 & 0.023 & 785 \\
Nonaccrual loans/assets & 0.004 & 0.004 & 0.007 & 781 \\
Assets (\$ billion) & 63.400 & 18.414 & 94.881 & 785 \\
Multistate & 0.480 & 0 & 0.500 & 800 \\
Financial manager wage $(\$ /$ hr $)$ & 27.080 & 25.870 & 4.775 & 738 \\
Per capita income $(\$ 10,000)$ & 2.770 & 2.724 & 0.452 & 796 \\
Pop. density (persons/sq. mi.) & 0.075 & 0.049 & 0.098 & 795 \\
Population (million) & 0.170 & 0.112 & 0.173 & 800 \\
Branch share (\%) & 8.707 & 7.514 & 6.872 & 755 \\
Markets & 44.674 & 12 & 68.014 & 783 \\
Thrift & 0.312 & 0 & 0.463 & 783 \\
Teller wage (\$/hr.) & 8.424 & 8.295 & 0.610 & 800 \\
Fixed assets expense/FA & 0.097 & 0.085 & 0.073 & 783 \\
Salary per employee $(\$ 1000)$ & 11.130 & 11.025 & 2.231 & 771 \\
Employees per branch & 23.048 & 19.437 & 17.188 & 775 \\
Unemployment rate & 3.946 & 3.500 & 2.058 & 800 \\
Mortgage delinq. rate & 1.094 & 1.010 & 0.464 & 800 \\
Loan officer wage $(\$ /$ hr) & 16.864 & 16.780 & 2.678 & 800 \\
HHI (0-1 scale) & 0.145 & 0.130 & 0.071 & 796 \\
In-migration rate & 7.039 & 6.842 & 2.266 & 796 \\
New England & 0.059 & 0 & 0.235 & 800 \\
Mid-Atlantic & 0.131 & 0 & 0.338 & 800 \\
E.N. Central & 0.165 & 0 & 0.371 & 800 \\
W.N. Central & 0.055 & 0 & 0.228 & 800 \\
South Atlantic & 0.220 & 0 & 0.415 & 800 \\
E.S. Central & 0.071 & 0 & 0.257 & 800 \\
W.S. Central & 0.106 & 0 & 0.308 & 800 \\
Mountain & 0.073 & 0 & 0.259 & 800 \\
\hline
\end{tabular}


Table 3: OLS Regression Results

\begin{tabular}{|c|c|c|c|c|c|c|c|c|}
\hline \multirow[b]{2}{*}{ Variable } & \multicolumn{2}{|c|}{ Interest Checking } & \multicolumn{2}{|c|}{ MMDA } & \multicolumn{2}{|c|}{ 6-month CD } & \multicolumn{2}{|c|}{ 12-month CD } \\
\hline & Coef. & Std. Err. & Coef. & Std. Err. & Coef. & Std. Err. & Coef. & Std. Err. \\
\hline Intercept & $3.724^{* *}$ & 0.436 & $4.386^{* *}$ & 0.548 & $6.689^{* *}$ & 0.427 & $6.782^{* *}$ & 0.357 \\
\hline Issues sub. debt & $0.108^{* *}$ & 0.047 & $-0.108^{*}$ & 0.060 & -0.060 & 0.047 & 0.028 & 0.039 \\
\hline (Issues sub.)*(rate) & -0.747 & 1.108 & -0.975 & 1.405 & $-1.832^{*}$ & 1.104 & -0.951 & 0.922 \\
\hline Rated & -0.007 & 0.048 & 0.018 & 0.064 & 0.057 & 0.048 & 0.018 & 0.040 \\
\hline Capital/assets & 1.064 & 0.802 & $2.690^{* *}$ & 1.001 & -0.681 & 0.784 & $-1.372^{* *}$ & 0.655 \\
\hline Nonaccr. loans/assets & $6.396^{*}$ & 3.401 & $9.948^{* *}$ & 3.112 & $4.312^{*}$ & 2.447 & $4.919^{* *}$ & 2.044 \\
\hline $\ln ($ Assets $(\$ 1000))$ & $-0.122^{* *}$ & 0.014 & $-0.089^{* *}$ & 0.018 & $-0.063^{* *}$ & 0.013 & $-0.065^{* *}$ & 0.011 \\
\hline Multistate & -0.009 & 0.044 & $0.104^{*}$ & 0.057 & 0.010 & 0.044 & 0.004 & 0.037 \\
\hline Fin. mgr. wage $(\$ / \mathrm{hr})$ & $-1.055^{*}$ & 0.569 & 0.717 & 0.720 & 0.800 & 0.567 & 0.559 & 0.474 \\
\hline PCI $(\$ 10,000)$ & 0.022 & 0.058 & -0.003 & 0.075 & -0.003 & 0.058 & 0.030 & 0.048 \\
\hline Pop. density & 0.117 & 0.320 & 0.192 & 0.402 & $-0.553^{*}$ & 0.317 & -0.405 & 0.265 \\
\hline Population (million) & -0.216 & 0.170 & -0.077 & 0.213 & 0.036 & 0.168 & -0.007 & 0.140 \\
\hline Branch share (\%) & 0.004 & 0.003 & -0.004 & 0.004 & $-0.011^{* *}$ & 0.003 & $-0.010^{* *}$ & 0.003 \\
\hline Markets & -0.051 & 0.371 & $-1.125^{* *}$ & 0.487 & 0.162 & 0.366 & -0.438 & 0.306 \\
\hline Thrift & $0.098^{*}$ & 0.056 & $0.195^{* *}$ & 0.071 & $0.199^{* *}$ & 0.055 & $0.162^{* *}$ & 0.046 \\
\hline Teller wage $(\$ / \mathrm{hr})$. & -4.146 & 4.628 & $-11.538^{* *}$ & 5.840 & $-13.893^{* *}$ & 4.582 & $-13.595^{* *}$ & 3.826 \\
\hline Fixed assets exp./FA & $-0.951^{* *}$ & 0.373 & 0.573 & 0.448 & -0.324 & 0.353 & -0.335 & 0.295 \\
\hline Salary/emp. (\$1000) & -0.004 & 0.009 & $0.033^{* *}$ & 0.012 & $0.021^{* *}$ & 0.009 & $0.024^{* *}$ & 0.008 \\
\hline Employees/branch & $0.002^{* *}$ & 0.001 & 0.001 & 0.001 & 0.001 & 0.001 & 0.000 & 0.001 \\
\hline Unemployment rate & -0.004 & 0.013 & -0.015 & 0.016 & -0.013 & 0.012 & -0.003 & 0.010 \\
\hline Mortgage delinq. rate & $-0.129 * *$ & 0.060 & $-0.363^{* *}$ & 0.076 & -0.091 & 0.060 & $-0.134^{* *}$ & 0.050 \\
\hline Loan ofcr. wage $(\$ / \mathrm{hr})$. & $2.069 * *$ & 0.862 & 0.909 & 1.088 & 1.306 & 0.847 & $1.522^{* *}$ & 0.707 \\
\hline HHI (0-1 scale) & $-0.586^{* *}$ & 0.297 & $-0.661^{*}$ & 0.377 & 0.053 & 0.293 & -0.012 & 0.245 \\
\hline In-migration rate & 0.271 & 1.086 & 0.321 & 1.387 & 0.804 & 1.079 & 1.029 & 0.901 \\
\hline New England & $-0.512^{* *}$ & 0.157 & -0.113 & 0.199 & -0.193 & 0.157 & -0.047 & 0.131 \\
\hline Mid-Atlantic & $-0.147^{*}$ & 0.083 & -0.057 & 0.104 & $-0.557^{* *}$ & 0.081 & $-0.142^{* *}$ & 0.068 \\
\hline E.N. Central & -0.051 & 0.091 & -0.131 & 0.115 & $-0.368^{* *}$ & 0.091 & $-0.265^{* *}$ & 0.076 \\
\hline W.N. Central & -0.116 & 0.108 & -0.085 & 0.136 & $-0.332^{* *}$ & 0.107 & $-0.264^{* *}$ & 0.090 \\
\hline South Atlantic & -0.101 & 0.075 & -0.081 & 0.095 & $-0.364^{* *}$ & 0.074 & $-0.254^{* *}$ & 0.062 \\
\hline E.S. Central & 0.140 & 0.102 & 0.130 & 0.132 & $-0.248^{* *}$ & 0.101 & -0.044 & 0.085 \\
\hline W.S. Central & 0.013 & 0.084 & -0.035 & 0.105 & $-0.460^{* *}$ & 0.083 & $-0.318^{* *}$ & 0.069 \\
\hline Mountain & 0.108 & 0.094 & 0.184 & 0.119 & $-0.223^{* *}$ & 0.094 & $-0.170^{* *}$ & 0.079 \\
\hline Adjusted $R^{2}$ & \multirow{2}{*}{\multicolumn{2}{|c|}{$\begin{array}{c}0.379 \\
678\end{array}$}} & \multirow{2}{*}{\multicolumn{2}{|c|}{$\begin{array}{c}0.341 \\
672\end{array}$}} & \multicolumn{2}{|c|}{0.309} & \multicolumn{2}{|c|}{0.375} \\
\hline $\mathrm{N}$ & & & & & \multicolumn{2}{|c|}{695} & \multicolumn{2}{|c|}{695} \\
\hline
\end{tabular}


Table 4: Random Effects Regression Results

\begin{tabular}{|c|c|c|c|c|c|c|c|c|}
\hline \multirow[b]{2}{*}{ Variable } & \multicolumn{2}{|c|}{ Interest Checking } & \multicolumn{2}{|c|}{ MMDA } & \multicolumn{2}{|c|}{ 6-month CD } & \multicolumn{2}{|c|}{ 12-month CD } \\
\hline & Coef. & Std. Err. & Coef. & Std. Err. & Coef. & Std. Err. & Coef. & Std. Err. \\
\hline Intercept & $4.018^{* *}$ & 0.408 & $4.444^{* *}$ & 0.545 & $5.951^{* *}$ & 0.401 & $6.193^{* *}$ & 0.330 \\
\hline Issues sub. debt & 0.109 & 0.072 & -0.091 & 0.076 & -0.059 & 0.059 & 0.039 & 0.046 \\
\hline (Issues sub.)*(rate) & -0.601 & 2.619 & -0.808 & 2.499 & -1.322 & 2.021 & -0.416 & 1.520 \\
\hline Rated & -0.011 & 0.085 & 0.040 & 0.090 & -0.066 & 0.070 & $-0.115^{* *}$ & 0.055 \\
\hline $\ln (\operatorname{Assets}(\$ 1000))$ & $-0.112^{* *}$ & 0.020 & $-0.085^{* *}$ & 0.022 & $-0.032^{*}$ & 0.017 & $-0.036^{* *}$ & 0.013 \\
\hline Multistate & -0.021 & 0.072 & 0.117 & 0.076 & -0.020 & 0.060 & -0.014 & 0.046 \\
\hline Fin. mgr. wage $(\$ / \mathrm{hr})$ & -0.988 & 0.750 & 0.215 & 0.874 & -0.760 & 0.670 & -0.525 & 0.534 \\
\hline PCI $(\$ 10,000)$ & 0.041 & 0.036 & 0.027 & 0.065 & 0.004 & 0.045 & 0.020 & 0.039 \\
\hline Pop. density & -0.012 & 0.237 & 0.016 & 0.376 & $-0.597^{* *}$ & 0.276 & $-0.514^{* *}$ & 0.232 \\
\hline Thrift & 0.066 & 0.082 & $0.169^{*}$ & 0.089 & $0.189 * *$ & 0.069 & $0.137 * *$ & 0.054 \\
\hline Teller wage $(\$ / \mathrm{hr})$. & $-7.481^{* *}$ & 2.959 & $-13.289^{* *}$ & 5.158 & $-7.366^{* *}$ & 3.670 & $-8.405^{* *}$ & 3.135 \\
\hline Fixed assets exp./FA & -0.454 & 0.478 & 0.638 & 0.503 & -0.246 & 0.389 & -0.300 & 0.307 \\
\hline Salary/emp. (\$1000) & -0.005 & 0.013 & $0.033^{* *}$ & 0.014 & $0.025 * *$ & 0.011 & $0.026^{* *}$ & 0.008 \\
\hline Employees/branch & 0.002 & 0.001 & 0.001 & 0.002 & 0.002 & 0.001 & 0.001 & 0.001 \\
\hline Unemployment rate & -0.004 & 0.007 & -0.007 & 0.013 & -0.003 & 0.009 & -0.001 & 0.008 \\
\hline Mortgage delinq. rate & $-0.206^{* *}$ & 0.041 & $-0.365^{* *}$ & 0.069 & $-0.090^{*}$ & 0.050 & $-0.135^{* *}$ & 0.043 \\
\hline Loan ofcr. wage $(\$ / \mathrm{hr}$.) & $1.397^{* *}$ & 0.580 & 1.223 & 0.964 & 0.709 & 0.690 & $1.168^{* *}$ & 0.586 \\
\hline HHI (0-1 scale) & $-0.569 * *$ & 0.209 & -0.550 & 0.345 & -0.017 & 0.248 & -0.131 & 0.209 \\
\hline In-migration rate & -0.697 & 0.663 & 0.811 & 1.187 & 1.129 & 0.837 & 0.786 & 0.718 \\
\hline New England & -0.193 & 0.127 & -0.035 & 0.190 & 0.002 & 0.141 & 0.089 & 0.117 \\
\hline$\sigma_{u}$ & & & & & & & & \\
\hline$\sigma_{e}$ & & & & & & & & \\
\hline$\rho$ & & & & & & & & \\
\hline $\mathrm{N}$ & & & & & & & & \\
\hline
\end{tabular}




\section{A Comparative Static Results}

\section{A.1 Wholesale Funds Rate}

First, consider the effect on the switch point $\tilde{D}_{R}$ of an incremental change in the wholesale funds rate. From (5), implicit differentiation gives

$$
\frac{\partial \tilde{D}_{R}}{\partial \bar{r}_{w}}=\frac{1}{2 r_{R}^{\prime}+\tilde{D}_{R} r_{R}^{\prime \prime}}>0 .
$$

The level of loans (and retail deposits) at which the bank switches from retail to wholesale deposits at the margin is increasing in the wholesale funds rate.

The effect of the wholesale funds rate on retail deposit supply is

$$
\frac{\partial D_{R}^{*}}{\partial \bar{r}_{W}}= \begin{cases}0 & \text { if } L^{*} \leq \tilde{D}_{R} \\ \frac{\partial \tilde{D}_{R}}{\partial \bar{r}_{w}} & \text { otherwise }\end{cases}
$$

That is, when wholesale funds are used, an increase in the wholesale rate increases equilibrium

retail deposits supplied. For lending below the switch point $\tilde{D}_{R}$, the wholesale funds rate has no effect on retail deposits. Upward-sloping retail deposit supply implies

$$
\frac{\partial r_{R}\left(D_{R}^{*}\right)}{\partial \bar{r}_{W}} \begin{cases}=0 & \text { if } L^{*} \leq \tilde{D}_{R} \\ >0 & \text { otherwise }\end{cases}
$$

The retail deposit rate is increasing in the wholesale funds rate if wholesale funds are being purchased; otherwise, it is unaffected by the wholesale rate.

Now consider the effect of $\bar{r}_{W}$ on total lending:

$$
\frac{\partial L^{*}}{\partial \bar{r}_{W}}= \begin{cases}0 & \text { if } L^{*} \leq \tilde{D}_{R} \\ \frac{1}{2 r_{L}^{\prime}+L^{*} r_{L}^{\prime \prime}} & \text { otherwise }\end{cases}
$$

The third assumption on loan demand in equation (3) guarantees that the second case in 
(A4) above is negative. So beyond the switch point $\tilde{D}_{R}$, total lending is decreasing in the wholesale rate. It follows that

$$
\frac{\partial r_{L}\left(L^{*}\right)}{\partial \bar{r}_{W}} \begin{cases}=0 & \text { if } L^{*} \leq \tilde{D}_{R} \\ >0 & \text { otherwise }\end{cases}
$$

\section{A.2 Retail Deposit Operating Cost}

Consider the case of operating costs for retail deposits. Let the total cost to the bank of retail deposits be

$$
C_{R}\left(r_{R}\left(D_{R}\right), D_{R} ; \theta_{R}\right)=r_{R}\left(D_{R}\right) D_{R}+c_{R}\left(D_{R} ; \theta_{R}\right)
$$

where $c_{R}$ is a function of operating costs and $\theta_{R}$ is a shift parameter, with

$$
\frac{\partial c_{R}\left(D_{R} ; \theta_{R}\right)}{\partial \theta_{R}}>0
$$

For simplicity, assume $c_{R}\left(D_{R} ; \theta_{R}\right)=\theta_{R} D_{R}$. Consistent with the initial setup, define $\tilde{D}_{R}$ as the level of retail deposits where the total marginal cost to the bank of retail deposits (including operating costs) equals the marginal cost of wholesale deposits:

$$
r_{R}\left(D_{R}\right)+D_{R} r_{R}^{\prime}\left(D_{R}\right)+\theta_{R}=\bar{r}_{W}
$$

Profit maximization results in an equilibrium value of $L^{*}$ that satisfies the following first-order condition:

$$
r_{L}(L)+L r_{L}^{\prime}(L)= \begin{cases}r_{R}(L)+L r_{R}^{\prime}(L)+\theta_{R} & \text { if } L^{*} \leq \tilde{D}_{R} \\ \bar{r}_{W} & \text { otherwise }\end{cases}
$$


Implicit differentiation gives

$$
\frac{\partial L^{*}}{\partial \theta_{R}}= \begin{cases}\frac{1}{2 r_{L}^{\prime}+L^{*} r_{L}^{\prime \prime}-\left[2 r_{R}^{\prime}+L^{*} r_{L}^{\prime \prime}\right]}<0 & \text { if } L^{*} \leq \tilde{D}_{R} \\ 0 & \text { otherwise }\end{cases}
$$

Thus, an increase in the marginal cost of retail deposits results in a lower level of total lending if no wholesale deposits are employed, and no change if wholesale deposits are funding loans at the margin.

The comparative statics for $\tilde{D}_{R}$ and $D_{R}^{*}$ are:

$$
\begin{gathered}
\frac{\partial \tilde{D}_{R}}{\partial \theta_{R}}=\frac{-1}{2 r_{R}^{\prime}+\tilde{D}_{R} r_{R}^{\prime \prime}}<0, \\
\frac{\partial D_{R}^{*}}{\partial \theta_{R}}= \begin{cases}\frac{\partial L^{*}}{\partial \theta_{R}}<0 & \text { if } L^{*} \leq \tilde{D}_{R}, \\
0 & \text { otherwise, }\end{cases}
\end{gathered}
$$

Thus, retail deposits decrease from an increase in $\theta_{R}$ for retail deposits below the switch point, and do not vary with retail deposit operating costs if wholesale funds are being used.

\section{A.3 Wholesale Deposit Operating Cost}

Now consider the original model with the addition of a constant marginal operating cost of wholesale funds $\theta_{W}$. Define $\tilde{D}_{R}$ to satisfy

$$
r_{R}\left(D_{R}\right)+D_{R} r_{R}^{\prime}\left(D_{R}\right)=\bar{r}_{W}+\theta_{W}
$$

Clearly, the effect on equilibrium values is identical to the effect of the wholesale funds rate $\bar{r}_{W}$. The comparative static results for $\theta_{W}$ are therefore identical to those of $\bar{r}_{W}$, and take 
the same form as the results shown in equations (A1) - (A4). To summarize,

$$
\begin{gathered}
\frac{\partial L^{*}}{\partial \theta_{W}}= \begin{cases}0 & \text { if } L^{*} \leq \tilde{D}_{R}, \\
\frac{1}{2 r_{L}^{\prime}+L^{*} r_{L}^{\prime \prime}}<0 & \text { otherwise },\end{cases} \\
\frac{\partial \tilde{D}_{R}}{\partial \theta_{W}}=\frac{1}{2 r_{R}^{\prime}+\tilde{D}_{R} r_{R}^{\prime \prime}}>0, \\
\frac{\partial D_{R}^{*}}{\partial \theta_{W}}= \begin{cases}0 & \text { if } L^{*} \leq \tilde{D}_{R}, \\
\frac{\partial \tilde{D}_{R}}{\partial \theta_{W}}>0 & \text { otherwise, }\end{cases} \\
\frac{\partial}{\partial \theta_{W}}\left(\frac{D_{W}^{*}}{D_{R}^{*}}\right)=\left\{\begin{array}{l}
0 \\
\frac{1}{\tilde{D}_{R}} \frac{\partial L^{*}}{\partial \theta_{W}}-\frac{L^{*}}{\left(\tilde{D}_{R}\right)^{2}} \frac{\partial \tilde{D}_{R}}{\partial \theta_{W}}<0 \quad \text { otherwise. }
\end{array}\right.
\end{gathered}
$$

\section{A.4 Loan Operating Cost}

Assume the parameter $\theta_{L}$ shifts loan operating costs by increasing total and marginal cost:

$$
\begin{aligned}
\frac{\partial c_{L}\left(L ; \theta_{L}\right)}{\partial \theta_{L}} & >0, \\
\frac{\partial}{\partial \theta_{L}}\left(c_{L}^{\prime}\right) & \geq 0 .
\end{aligned}
$$

Define $\tilde{D}_{R}$ as originally defined in equation (5). The comparative statics for $\theta_{L}$ are

$$
\begin{gathered}
\frac{\partial L^{*}}{\partial \theta_{L}}=\left\{\begin{array}{cc}
\frac{\frac{\partial}{\partial \theta_{L}}\left(c_{L}^{\prime}\right)}{2 r_{L}^{\prime}+L^{*} r_{L}^{\prime \prime}-\left(2 r_{R}^{\prime}+L^{*} r_{R}^{\prime \prime}\right)-c_{L}^{\prime \prime}}<0 & \text { if } L^{*} \leq \tilde{D}_{R} \\
\frac{\partial}{\partial \theta_{L}}\left(c_{L}^{\prime}\right) & \text { otherwise } \\
2 r_{L}^{\prime}+L^{*} r_{L}^{\prime \prime}-c_{L}^{\prime \prime} & <0
\end{array}\right. \\
\frac{\partial \tilde{D}_{R}}{\partial \theta_{L}}=0,
\end{gathered}
$$




$$
\frac{\partial D_{R}^{*}}{\partial \theta_{L}}= \begin{cases}\frac{\partial L^{*}}{\partial \theta_{L}}<0 & \text { if } L^{*} \leq \tilde{D}_{R} \\ 0 & \text { otherwise }\end{cases}
$$

\section{A.5 Retail Deposit Supply}

Consider a parameter $\sigma_{R}$ that shifts the retail deposit supply function $r_{R}\left(D_{R} ; \sigma_{R}\right)$. Assume

$$
\begin{array}{r}
\frac{\partial r_{R}}{\partial \sigma_{R}}<0, \\
\frac{\partial}{\partial \sigma_{R}}\left(r_{R}^{\prime}\right) \leq 0,
\end{array}
$$

where $r_{R}^{\prime}=\partial r_{R}\left(D_{R} ; \sigma_{R}\right) / \partial D_{R}$. This implies that $\sigma_{R}$ shifts the supply curve down and right, without steepening the slope. Define $\tilde{D}_{R}$ to satisfy

$$
r_{R}\left(D_{R} ; \sigma_{R}\right)+D_{R} r_{R}^{\prime}\left(D_{R} ; \sigma_{R}\right)=\bar{r}_{W}
$$

The relevant comparative statics are

$$
\begin{gathered}
\frac{\partial L^{*}}{\partial \sigma_{R}}= \begin{cases}\frac{\frac{\partial r_{R}}{\partial \sigma_{R}}+L^{*} \frac{\partial}{\partial \sigma_{R}}\left(r_{R}^{\prime}\right)}{2 r_{L}^{\prime}+L^{*} r_{L}^{\prime \prime}-\left(2 r_{R}^{\prime}+L^{*} r_{R}^{\prime \prime}\right)}>0 & \text { if } L^{*} \leq \tilde{D}_{R}, \\
0 & \text { otherwise, }\end{cases} \\
\frac{\partial \tilde{D}_{R}}{\partial \sigma_{R}}=\frac{-\left[\frac{\partial r_{R}}{\partial \sigma_{R}}+\tilde{D}_{R} \frac{\partial}{\partial \sigma_{R}}\left(r_{R}^{\prime}\right)\right]}{2 r_{R}^{\prime}+\tilde{D}_{R} r_{R}^{\prime \prime}}>0, \\
\frac{\partial D_{R}^{*}}{\partial \sigma_{R}}= \begin{cases}\frac{\partial L^{*}}{\partial \sigma_{R}}>0 & \text { if } L^{*} \leq \tilde{D}_{R}, \\
\frac{\partial \tilde{D}_{R}}{\partial \sigma_{R}}>0 & \text { otherwise },\end{cases} \\
\frac{\partial}{\partial \sigma_{R}}\left(\frac{D_{W}^{*}}{D_{R}^{*}}\right)= \begin{cases}0 & \text { if } L^{*} \leq \tilde{D}_{R}, \\
-\frac{L^{*}}{\left(\tilde{D}_{R}\right)^{2}} \frac{\partial \tilde{D}_{R}}{\partial \sigma_{R}}<0 & \text { otherwise. }\end{cases}
\end{gathered}
$$




\section{A.6 Loan Demand}

Consider a parameter $\sigma_{L}$ that shifts loan demand $r_{L}\left(L ; \sigma_{L}\right)$. Assume

$$
\begin{aligned}
\frac{\partial r_{L}}{\partial \sigma_{L}} & >0, \\
\frac{\partial}{\partial \sigma_{L}}\left(r_{L}^{\prime}\right) & \geq 0 ;
\end{aligned}
$$

that is, $\sigma_{L}$ increases loan demand by shifting the function away from the origin without flattening the slope. Define $\tilde{D}_{R}$ as was specified in the original model to satisfy

$$
r_{R}\left(D_{R}\right)+D_{R} r_{R}^{\prime}\left(D_{R}\right)=\bar{r}_{W} .
$$

The comparative statics are as follows:

$$
\begin{aligned}
& \frac{\partial \tilde{D}_{R}}{\partial \sigma_{L}}=0, \\
& \frac{\partial D_{R}^{*}}{\partial \sigma_{L}}= \begin{cases}\frac{\partial L^{*}}{\partial \sigma_{L}}>0 & \text { if } L^{*} \leq \tilde{D}_{R} \\
\frac{\partial \tilde{D}_{R}}{\partial \sigma_{R}}=0 & \text { otherwise }\end{cases}
\end{aligned}
$$

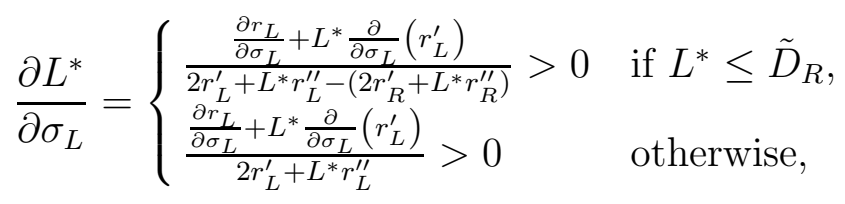




\section{B Welfare Effects of a Change in the Wholesale Rate}

The expressions for surplus to borrowers, depositors and the bank are:

$$
\begin{aligned}
\text { borrower surplus } & =\int_{0}^{L^{*}}\left[r_{L}(x)-r_{L}\left(L^{*}\right)\right] d x \\
\text { depositor surplus } & =\int_{0}^{D_{R}^{*}}\left[r_{R}\left(D_{R}^{*}\right)-r_{R}(x)\right] d x \\
\text { bank surplus } & =\int_{0}^{\tilde{D}_{R}}\left[r_{L}\left(L^{*}\right)-r_{R}\left(\tilde{D}_{R}\right)\right] d x+\int_{\tilde{D}_{R}}^{L^{*}}\left[r_{L}\left(L^{*}\right)-\bar{r}_{W}\right] d x \\
& =r_{L}\left(L^{*}\right) L^{*}-r_{R}\left(\tilde{D}_{R}\right) \tilde{D}_{R}-\bar{r}_{W}\left(L^{*}-\tilde{D}_{R}\right) .
\end{aligned}
$$

Differentiating the terms above with respect to $\bar{r}_{W}$ gives

$$
\begin{aligned}
\frac{\partial \text { (borrower surplus })}{\partial \bar{r}_{W}} & =-L^{*} r_{L}^{\prime}\left(L^{*}\right) \frac{\partial L^{*}}{\partial \bar{r}_{W}}<0, \\
\frac{\partial(\text { depositor surplus })}{\partial \bar{r}_{W}} & =\tilde{D}_{R} r_{R}^{\prime}\left(\tilde{D}_{R}\right) \frac{\partial \tilde{D}_{R}}{\partial \bar{r}_{W}}>0, \\
\frac{\partial(\text { bank surplus })}{\partial \bar{r}_{W}} & =-\left(L^{*}-\tilde{D}_{R}\right)=-D_{W}^{*}<0 .
\end{aligned}
$$

A higher wholesale funds rate therefore benefits retail depositors, but decreases the welfare of borrowers and the bank. The sum of the derivatives above gives the derivative of total surplus with respect to the wholesale rate. Substituting the terms in (A1) and (A4), the derivative is

$$
\frac{\partial(\text { total surplus })}{\partial \bar{r}_{W}}=\tilde{D}_{R}\left(1+\frac{1}{2+\tilde{D}_{R} \frac{r_{R}^{\prime \prime}\left(\tilde{D}_{R}\right)}{r_{R}^{\prime}\left(\tilde{D}_{R}\right)}}\right)-L^{*}\left(1+\frac{1}{2+L^{*} \frac{r_{L}^{\prime \prime}\left(L^{*}\right)}{r_{L}^{\prime}\left(L^{*}\right)}}\right)
$$

Hence, the effect on total surplus of the wholesale funds rate depends on the relative curvature and magnitudes of retail deposit supply and loan demand. With symmetric curvature of these functions, the gains to borrowers from a drop in $\bar{r}_{W}$ exceed the loss to retail depositors. 


\section{Markets included in the Sample}

\begin{tabular}{|c|c|c|c|}
\hline & Market & State & Market Frequency \\
\hline 1 & Albany & New York & 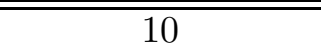 \\
\hline 2 & Albuquerque & New Mexico & 5 \\
\hline 3 & Allentown - Bethlehem & Pennsylvania & 7 \\
\hline 4 & Anchorage & Alaska & 4 \\
\hline 5 & Atlanta & Georgia & 10 \\
\hline 6 & Augusta, GA - Aiken, SC & Georgia & 4 \\
\hline 7 & Austin - San Marcos & Texas & 4 \\
\hline 8 & Bakersfield & California & 8 \\
\hline 9 & Baltimore & Maryland & 10 \\
\hline 10 & Baton Rouge & Louisiana & 4 \\
\hline 11 & Billings & Montana & 4 \\
\hline 12 & Birmingham & Alabama & 6 \\
\hline 13 & Boise & Idaho & 4 \\
\hline 14 & Boston & Massachusetts & 10 \\
\hline 15 & Bristol - Kingsport & Tennessee & 4 \\
\hline 16 & Buffalo & New York & 9 \\
\hline 17 & Burlington & Vermont & 5 \\
\hline 18 & Canton - Massillon & Ohio & 4 \\
\hline 19 & Casper - Cheyenne & Wyoming & 4 \\
\hline 20 & Charleston - North Charleston & South Carolina & 4 \\
\hline 21 & Charleston & West Virginia & 4 \\
\hline 22 & Charlotte & North Carolina & 10 \\
\hline 23 & Chattanooga & Tennessee & 5 \\
\hline 24 & Chicago & Illinois & 10 \\
\hline 25 & Cincinnati & Ohio & 10 \\
\hline 26 & Cleveland & Ohio & 10 \\
\hline 27 & Colorado Springs & Colorado & 6 \\
\hline 28 & Columbia & South Carolina & 4 \\
\hline 29 & Columbus & Ohio & 10 \\
\hline 30 & Concord - Manchester & New Hampshire & 4 \\
\hline 31 & Dallas & Texas & 10 \\
\hline 32 & Dayton & Ohio & 9 \\
\hline 33 & Daytona Beach & Florida & 6 \\
\hline 34 & Denver - Boulder - Greeley & Colorado & 10 \\
\hline 35 & Des Moines & Iowa & 4 \\
\hline 36 & Detroit & Michigan & 10 \\
\hline 37 & El Paso & Texas & 4 \\
\hline 38 & Fargo & North Dakota & 4 \\
\hline 39 & Fort Wayne & Indiana & 4 \\
\hline
\end{tabular}




\begin{tabular}{|c|c|c|c|}
\hline & Market & State & Market Frequency \\
\hline 40 & Fresno & 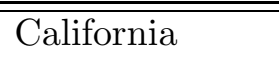 & 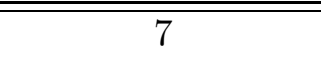 \\
\hline 41 & Grand Rapids & Michigan & 11 \\
\hline 42 & Greensboro & North Carolina & 6 \\
\hline 43 & Greenville - Spartanburg & South Carolina & 8 \\
\hline 44 & Harrisburg - Lebanon - York & Pennsylvania & 4 \\
\hline 45 & Hartford & Connecticut & 10 \\
\hline 46 & Honolulu & Hawaii & 4 \\
\hline 47 & Houston & Texas & 10 \\
\hline 48 & Indianapolis & Indiana & 10 \\
\hline 49 & Jackson & Mississippi & 6 \\
\hline 50 & Jacksonville & Florida & 10 \\
\hline 51 & Kalamazoo - Battle Creek & Michigan & 4 \\
\hline 52 & Kansas City & Kansas & 10 \\
\hline 53 & Kansas City & Missouri & 6 \\
\hline 54 & Knoxville & Tennessee & 4 \\
\hline 55 & Lakeland - Winter Haven & Florida & 4 \\
\hline 56 & Lancaster - Reading & Pennsylvania & 6 \\
\hline 57 & Lansing - East Lansing & Michigan & 4 \\
\hline 58 & Las Vegas & Nevada & 5 \\
\hline 59 & Lexington & Kentucky & 4 \\
\hline 60 & Little Rock & Arkansas & 4 \\
\hline 61 & Los Angeles & California & 10 \\
\hline 62 & Louisville & Kentucky & 10 \\
\hline 63 & Madison & Wisconsin & 4 \\
\hline 64 & McAllen - Edinburg - Mission & Texas & 4 \\
\hline 65 & Melbourne - Titusville - Palm Bay & Florida & 4 \\
\hline 66 & Memphis & Tennessee & 9 \\
\hline 67 & Miami/Ft. Lauderdale & Florida & 12 \\
\hline 68 & Milwaukee - Racine & Wisconsin & 10 \\
\hline 69 & Minneapolis - St. Paul & Minnesota & 10 \\
\hline 70 & Mobile & Alabama & 4 \\
\hline 71 & Modesto & California & 6 \\
\hline 72 & Nashville & Tennessee & 10 \\
\hline 73 & New Orleans & Louisiana & 10 \\
\hline 74 & New York & New York & 10 \\
\hline 75 & Newark & New Jersey & 10 \\
\hline 76 & Norfolk - Virginia Beach & Virginia & 10 \\
\hline 77 & Oklahoma City & Oklahoma & 10 \\
\hline 78 & Omaha & Nebraska & 4 \\
\hline 79 & Orlando & Florida & 10 \\
\hline 80 & Philadelphia & Pennsylvania & 10 \\
\hline 81 & Phoenix - Mesa & Arizona & 9 \\
\hline 82 & Pittsburgh & Pennsylvania & 10 \\
\hline
\end{tabular}




\begin{tabular}{cl|l|c}
\hline & Market & State & Market Frequency \\
\hline \hline 83 & Portland & Maine & 4 \\
84 & Portland & Oregon & 9 \\
85 & Providence & Rhode Island & 10 \\
86 & Raleigh - Durham - Chapel Hill & North Carolina & 9 \\
87 & Rapid City - Sioux Falls & South Dakota & 3 \\
88 & Richmond & Virginia & 10 \\
89 & Rochester & New York & 11 \\
90 & Sacramento & California & 10 \\
91 & Saginaw - Bay City - Midland & Michigan & 4 \\
92 & Salt Lake City & Utah & 9 \\
93 & San Antonio & Texas & 9 \\
94 & San Diego & California & 10 \\
95 & San Francisco & California & 10 \\
96 & Sarasota - Bradenton & Florida & 6 \\
97 & Scranton - Wilkes Barre & Pennsylvania & 4 \\
98 & Seattle & Washington & 10 \\
99 & Shreveport - Bossier City & Louisiana & 4 \\
100 & Spokane & Washington & 4 \\
101 & Springfield & Massachusetts & 4 \\
102 & St. Louis & Missouri & 10 \\
103 & Stockton - Lodi & California & 5 \\
104 & Syracuse & New York & 11 \\
105 & Tampa - St. Petersburg & Florida & 10 \\
106 & Toledo & Ohio & 4 \\
107 & Tucson & Arizona & 4 \\
108 & Tulsa & Oklahoma & 11 \\
109 & Washington & District of Col. & 10 \\
110 & West Palm Beach & Florida & 10 \\
111 & Wichita & Kansas & 5 \\
112 & Wilmington & Delaware & 5 \\
113 & Youngstown - Warren - Akron & Ohio & 4 \\
\hline & Total Observations & & 806 \\
\hline & & & \\
\hline
\end{tabular}




\section{References}

Adams, R., L. Röller, and R. Sickles, "Measuring market power for outputs and inputs: An empirical application to banking," 2002. FEDS working paper 2002-52, Federal Reserve Board.

Amel, D. and M. Starr-McCluer, "Market definition in banking: recent evidence," The Antitrust Bulletin, 2002, Spring, 63-89.

and T. Hannan, "Establishing banking market definitions through estimation of residual deposit supply equations," Journal of Banking and Finance, 1999, 23 (11), 1667-1690.

Berger, A. and D. Humphrey, "Measurement and efficiency issues in commercial banking," in Z. Griliches, ed., Output Measurement in the Service Sectors, National Bureau of Economic Research, Studies in Income and Wealth, Vol. 56, Chicago: University of Chicago Press, 1992, pp. 245-279.

and T. Hannan, "The price-concentration relationship in banking," Review of Economics and Statistics, 1989, 71 (2), 291-299.

Dick, A., "Demand estimation and market power in the banking industry," 2002. FEDS working paper 2002-58, Federal Reserve Board.

Eaton, B. and R. Lipsey, "Product differentiation," in R. Schmalensee and R. Willig, eds., Handbook of Industrial Organization, Amsterdam: North-Holland, 1996, pp. 723-768.

Freixas, X. and J. Rochet, Microeconomics of Banking, Cambridge: MIT Press, 1997.

Frisch, R., Theory of Production, Chicago: Rand McNally and Company, 1965. 
Furfine, C., "Banks as monitors of other banks: evidence from the overnight federal funds market," Journal of Business, 2001, 74 (1), 33-57.

Greene, W., Econometric Analysis, Fourth Edition, New Jersey: Prentice Hall, 2000.

Hancock, D., "The financial firm: Production with monetary and nonmonetary goods," Journal of Political Economy, 1985, 93 (5), 859-880.

Hausman, J., "Specification tests in econometrics," Econometrica, 1978, 46 (6), 1251-1271.

Heitfield, E., "What do interest rate data say about the geography of retail banking markets?," The Antitrust Bulletin, 1999, 44 (2), 333-348.

Hughes, J. and L. Mester, "Bank capitalization and cost: evidence of scale economies in risk management and signaling," Review of Economics and Statistics, 1998, 80 (2), $314-325$.

Jayaratne, J. and D. Morgan, "Capital market frictions and deposit constraints at banks," Journal of Money, Credit and Banking, 2000, 32 (1), 74-92.

Kashyap, A. and J. Stein, "What do a million observations on banks say about the transmission of monetary policy?," American Economic Review, 2000, 90 (3), 407-428.

Kiser, E., "Household switching behavior at depository institutions: evidence from survey data," The Antitrust Bulletin, Winter 2002, 47 (4), 619-640.

Klein, M., "A theory of the banking firm," Journal of Money, Credit and Banking, 1971, 3, 205-218.

Klemperer, P., "Competition when consumers have switching costs: an overview with applications to industrial organization, macroeconomics, and international trade," Review of Economic Studies, 1995, 62, 515-539. 
Massoud, N. and D. Bernhardt, "'Rip-off' ATM Surcharges," RAND Journal of Economics, 2002, 33 (1), 96-115.

Monti, M., "Deposit, credit, and interest rate determination under alternative bank objectives," in G. P. Szego and K. Shell, eds., Mathematical methods in investment and finance, Amsterdam: North-Holland, 1972.

Morgan, D. and K. Stiroh, "Market Discipline of Banks: the Asset Test," 2000. Working paper, Federal Reserve Bank of New York.

Prager, R. and T. Hannan, "Do Substantial Horizontal Mergers Generate Significant Price Effects? Evidence from the Banking Industry," Journal of Industrial Economics, 1998, $46(4), 433-52$.

Santomero, A., "Modeling the banking firm: a survey," Journal of Money, Credit and Banking, 1984, 16 (4), 576-602.

Sealey, C. and J. Lindley, "Inputs, outputs, and a theory of production and cost at depository financial institutions," Journal of Finance, 1977, 32 (4), 1251-1266.

Sharpe, S., "The effect of consumer switching costs on prices: A theory and its application to the bank deposit market," Review of Industrial Organization, 1997, 12 (1), 79-94.

Tobin, J., "Chapter 8 - The theory of commercial banking," 1958. Unpublished manuscript. 